\title{
NUTRITIONAL CHANGES IN POWDERED RED PEPPER UPON IN VITRO INFECTION OF ASPERGILLUS FLAVUS
}

\author{
Smita Tripathi*1; H.N. Mishra ${ }^{1}$ \\ ${ }^{1}$ Food Technology Laboratory, Department of Agricultural and Food Engineering, Indian Institute of Technology, \\ Kharagpur- 721302
}

Submitted: February 23, 2008; Returned to authors for corrections: June 29, 2008; Approved: February 25, 2009.

\begin{abstract}
Quantitative losses in various biochemical constituents like capsaicin, carotenes, ascorbic acid, polyphenols, mineral matter, sugars (soluble and insoluble), protein and fat were estimated after the successful growth of Aspergillus flavus for 30 days on powdered red pepper. The fungal biomass was measured by ergosterol content and Aflatoxin $\mathrm{B}_{1}$ by HPLC. Amongst the various nutritional constituents evaluated for nutritional losses and changes the highest nutritional loss was reported in total carotenoids $(88.55 \%)$ followed by total sugars (85.5\%). The protein content of the infected sample increased from $18.01 \%$ to $23 \%$. The nutritional profile of chilli powder (Capsicum annum var. sannam L.) shows highest share of total soluble sugars (32.89\%) and fiber content (21.05\%), followed by protein (18.01\%) and fat (13.32\%) making it an ideal solid substrate for mould growth. At the end of incubation the fungal biomass was $192.25 \mathrm{mg} / 100$ gram powder, total plate count $17.5 \times 10^{4} \mathrm{CFU} / \mathrm{g}$ and Aflatoxin $\mathrm{B}_{1}$ content was $30.06 \mu \mathrm{g} / \mathrm{kg}$.
\end{abstract}

Keywords: Aspergillus flavus, chili powder, nutritional changes, aflatoxin

\section{INTRODUCTION}

Many agricultural commodities such as cereals, oilseeds, dry fruits and spices have been reported to be contaminated with toxigenic moulds and aflatoxin $\mathrm{B}_{1}$ under faulty storage conditions $(1,13,21)$. Chillies are reported to be contaminated with moulds and their toxic metabolites and Aspergillus flavus is the predominant mold on chilli samples in several cases $(9,11,18,25,26)$.

The occurrence of Aspergillus spp. in spices pose a serious health hazards as these are toxigenic moulds which produce aflatoxins; a potent hepatotoxic and carcinogen. Powdered red pepper is often added in variety of Indian snack foods without any processing or raw, thus presence of toxic metabolites and moulds will have serious implications on nutrition and health of human population (5). In the US, the FDA uses an action level of $20 \mu \mathrm{g} / \mathrm{kg}$ as the maximum residue limit allowed in food for human consumption, except for milk. For overall sanitary precaution principle, the European Union has enacted very severe aflatoxin tolerance standards of $2 \mu \mathrm{g} / \mathrm{kg}$ for aflatoxin $\mathrm{B}_{1}$ and $4 \mu \mathrm{g} / \mathrm{kg}$ for total aflatoxins for commodities used in direct human consumption (6).

Onifade and Agboola (17) studied the effect of fungal infection on proximate nutrient composition of coconut and recorded significant decrease in carbohydrate and crude fibre content. Significant biochemical changes and decrease in total phenols and sugar content of fruits of bell pepper in response to infection by Phytophthora nicotianae is reported (7). Azad (3) reported that there was reduction in the content of sugar, ascorbic acid, nitrogen and sulphur in chilli fruits infected with Colletotrichum capsici. Prasad et al. (19) observed the association of various moulds with chillies and their role in decay and discolouration. They reported that Aspergillus flavus, A. terreus, A. candidus, A. niger, A. sclerotium, Fusarium moniliforme, F. sporotrichioides, Syncephalastrum racemosum, Penicillium corylophilum and Paecilomyces varioti were commonly found on decaying chilli fruits stored in humid region. They also noticed the decrease in capsaicin content due to

*Corresponding Author. Mailing address: Food Technology Laboratory, Agricultural and Food Engineering Department, Indian Institute of Technology Kharagpur, 721 302. Fax: (03222) 282288, 282244, 255303. Phone: (03222) 281323. E-mail: smita145tripathi@yahoo.com 
fungal infection. Sauer (24) reported effects of fungal infection on nutritional value, toxicity and germination in grains.

In this study we investigated the extent of fungal growth by estimating the ergosterol content and its effect on quality of red pepper powder in terms of nutritional changes and $\mathrm{AFB}_{1}$ content.

\section{MATERIALS AND METHODS}

\section{Reagents}

Analytical grade ergosterol standard ( $>85 \%$ pure) was procured from Sigma Chemical Company (St.Louis, Missouri, USA). HPLC grade Aflatoxin $\mathrm{B}_{1}$ standard $(1 \mu \mathrm{g} / \mathrm{mL}$ in methanol) was purchased from Supelco, Bellefonte, PA, USA. HPLC grade standard capsaicin (> 97\% pure) and DPPH (>85\% pure) from Fluka, Germany. Potato dextrose agar, yeast, bacteriological peptone, ferric ammonium citrate, dichloran, agar, dihydrogen potassium phosphate $\left(\mathrm{KH}_{2} \mathrm{PO}_{4}\right)$, dipotassium hydrogen phosphate $\left(\mathrm{K}_{2} \mathrm{HPO}_{4}\right)$ for buffer preparation and $\beta$-Carotene standard (> 97\% pure) was procured from Himedia Laborateries Private Limited, Mumbai, India. The culture media was microbiological grade and other reagents were analytical grade. AR grade Guaiacol and 2, 6- dichlorophenol - indophenol dye; HPLC grade trifluoracetic acid, acetonitrile, methanol, tetrahydrofuran from Merck Specialties Private Limited, Mumbai, India.

\section{Microorganism and spore suspension preparation}

Aspergillus flavus NRRL 3357 was obtained from the U.S. Department of Agriculture, Northern Regional Research Center, Peoria, IL, USA. It was maintained on Potato Dextrose Agar at 4 $\pm 1^{\circ} \mathrm{C}$. Spore suspensions were prepared from 5 day old A. flavus NRRL 3357 cultured on PDA slants (pH $5.7 \pm 1$ ) at $28 \pm 1^{\circ} \mathrm{C}$ and the spores were harvested with $10 \mathrm{~mL}$ of sterile potassium phosphate buffer having pH $5.7 \pm 1$ and sterilized through membrane $(0.45 \mu \mathrm{m})$ filtration. Spore suspension was adjusted with the same solution to give a final spore concentration of 4.7 $\mathrm{X} 10^{6}$ spores per $\mathrm{mL}$ and was utilized the same day.

\section{Preparation of Substrate and Incubation}

Red pepper (Capsicum annum var. sannam L.) of good quality was procured from Indian exporter (Indian Mart, Andhra Pradesh, India). It was powdered in laboratory mixer (Kenstar multi purpose food processor and mixer grinder, model: MF0204, India) sieved and stored in airtight polythene pouches at $4^{\circ} \mathrm{C}$ in desiccators for further use in experimental procedures. 100 grams of sample were taken in duplicates and autoclaved at $121^{\circ} \mathrm{C}$ under a pressure of $15 \mathrm{lb} / \mathrm{in}^{2}$ for 15 minutes to remove any microbial contaminant. Each sample was inoculated with 3 $\mathrm{mL}$ of spore suspensions (initial inoculum level $10^{4}$ spores $/ \mathrm{mL}$ ) in sterile potassium phosphate buffer $(\mathrm{pH} 5.7 \pm 1)$. The uninoculated sample was considered as control. The inoculated sample was incubated in sterile conditions at temperature $28 \pm$ $1{ }^{\circ} \mathrm{C}$ and relative humidity of $90 \% \pm 1 \%$ for 30 days in Environmental Test Chamber (Remi, India Private Ltd, Model CH 10S).

\section{Measurement of fungal biomass}

Extent of fungal invasion was measured by ergosterol content of the infected samples according to method described by Naewbanij et al. (16) using precoated Silica gel-G TLC plates (20X $20 \mathrm{~cm}$, coating $500 \mu \mathrm{m}$ thick, G-25 HR, Glaxo Laboratories, India) and ultraviolet spectroscopy to quantitate at $282 \mathrm{~nm}$. The content was expressed as mg dry weight mycelium / g powder).

\section{Total Plate count}

Plate counts were done by standard procedures using Aspergillus flavus \& Aspergillus parasiticus agar: Yeast -20 $\mathrm{g}$, Bacteriological peptone: $10 \mathrm{~g}$, Ferric ammonium citrate: 0.1 g, Dichloran: 0.2\% in ethanol (1 mL), Agar: $15 \mathrm{~g}$, Distilled water: 1 litre.

\section{Aflatoxin $B_{1}$ analysis}

Aflatoxin in chilli samples was detected after derivatization of $\mathrm{AFB}_{1}$ with trifluoracetic acid to aflatoxin $\mathrm{B}_{2 \mathrm{a}}$ by HPLC (Shimadzu LC7A RF-535T system, Japan) with fluorescence detector and xenon lamp source by the method described by Vasanthi et al. (27). The chromatogram peaks were integrated on a Shimadzu-C-R6A chromatopac integrator. The HPLC column used was a reverse phase column with Zorbax ODS Packing ( $5 \mu \mathrm{m}$ particle size $) 4.6 \mathrm{~mm}$ i.d $\times 25 \mathrm{~cm}$ length. The HPLC operation conditions were Excitation wave length - $365 \mathrm{~nm}$, Emission wavelength - $440 \mathrm{~nm}$, Working pressure - 170-180 kg / $\mathrm{cm}^{2}$, Pressure maximum - $200 \mathrm{~kg} / \mathrm{cm}^{2}$, Mobile phase- Wateracetonitrile-methanol - tetrahydrofuran $(50: 25: 16: 9)$, Flow rate $-1 \mathrm{~mL} /$ minute.

\section{Nutritional analysis}

Total capsaicin. Capsaicin was measured by colorometric method (22). Capsaicin was extracted using dry acetone and then absorbance was read at $650 \mathrm{~nm}$ of the clear blue colored solution. The concentration of the sample was calculated from the standard curve prepared using capsaicin standard and expressed in $\mu \mathrm{g} / 100 \mathrm{~g}$ dry weight basis.

Total carotenoids. Carotenoids were extracted \& estimated by spectrophotometric method (23). Absorbance was measured at $436 \mathrm{~nm}$; concentration calculated from the standard curve and expressed in mg / $100 \mathrm{~g}$ dry weight of chili powder.

Total phenolics \& Radical scavenging activity. The content of total phenolic compound was determined by Folin - Ciocalteau method (12). The concentration (in Guaiacol equivalent - GE) was determined from the standard curve and expressed in $\mathrm{mg} /$ $100 \mathrm{~g}$ plant material. Antioxidant potential was estimated by 2,2 - 
Diphenyl-1-picrylhydrazyl (DPPH) assay by slightly modified method of Brand-Williams et al. (8). $100 \mu \mathrm{L}$ of chilli extract in methanol was added to $0.5 \mathrm{~mL}$ solution of 2, 2-diphenyl-1-pycrylhydrazil $(0.25 \mathrm{mM}$ in $95 \%$ methanol). Mixture was shaken and allowed to stand at room temperature in dark for $15 \mathrm{~min}$. Absorption of blank sample (time $=0 \mathrm{~min}$ ) was also prepared and its absorbance measured immediately. Decrease in absorbance was measured at $517 \mathrm{~nm}$ using a spectrophotometer. Percent inhibition was calculated from control using formula $\%$ inhibition $=(\mathrm{Ab}-\mathrm{Aa} / \mathrm{Ab}) * 100$, where, $\mathrm{Ab}$ is absorption of blank sample (time $=0 \mathrm{~min}$ ) and $\mathrm{Aa}$ is absorption of extract at (time $=$ $15 \mathrm{~min})$.

Ascorbic acid content. Ascorbic acid was quantitatively determined according to 2, 6- dichlorophenol - indophenol dye method as described by Jones and Hughes (14).

Proximate Compositon. Moisture, total ash (mineral matter), crude fiber, crude fat, total sugars and total protein content was determined by standard official methods of analysis (2) and expressed in percentage.

\section{RESULTS AND DISCUSSION}

From the present study it was seen that there is appreciable losses in the important biochemical constituents of chili powder upon mould growth. Red pepper powder proved to be an ideal substrate for Aspergillus flavus growth and aflatoxin production. The initial moisture content of the powder was $8.04 \% \mathrm{db}$ and upon infection and storage the moisture content raised to $24.05 \%(\mathrm{db})$. High moisture content helps in survival and growth of the mould. After 30 days of infection dense mycelial mat and sporulation (conidia) were prominent. The nutritional content was estimated on dry weight basis. The chili powder was inoculated with initial inoculum level of $10^{4}$ spores / 100 gram of powder. The total fungal count at initial days of incubation was relatively low but increased from $4.2 \times 10^{4}$ to $18.9 \times 10^{4}$ to CFU / g; the growth became stable after 20 days,
Table 1. From the Fig. 1 we can infer that fungal biomass and aflatoxin production increased proportionally with increase in storage duration but aflatoxin production only started after 10 days of incubation time. Also, at the initial 10 days of incubation the rate of fungal growth was slow. The maximum Aflatoxin $B_{1}$ $\left(\mathrm{AFB}_{1}\right)$ produced in chili powder was $32.47 \mu \mathrm{g} / \mathrm{kg}$ after 25 days of storage.

Table 1 presents the nutritional information about the changes in important biochemical constituents of red pepper powder during mould infection and storage; most of these parameters studied are also major quality criteria's for pepper export and consumption. It is evident from the table 1 that except total proteins all other constituents showed remarkable losses due to fungal growth. Total protein content increased from $18.01 \%$ to $23 \%$. Onifade and Agboola (17) also observed similar trend in increase in protein content due to fungal infection in coconut and postulated that proliferation of microorganism synthesize several enzyme proteins and sometimes cause rearrangement of nutritional composition of substrate due to formation of several degradation products thereby increasing its protein content. From Fig. 2 we can see that maximum nutritional losses were encountered for total carotenoids, sugars and fat. In all the biochemical constituent studied at initial incubation days there were no significant drop in the values but after 20 days of infection due to increase in fungal biomass there is considerable drop in all the constituents. The growing fungus utilizes the constituents of substrate for its growth may be the reason for same.

Moulds acquire nutrients by producing extracellular enzymes to break down organic material or the complex food sources. The resulting small molecules are then absorbed by the myceilium to fuel additional fungal growth. Aspergillus $s p$. are known to produce pectinase, xylanases etc. which breakdown the hemicellulose, cellulose, lignin or all the insoluble carbohydrates (crude fiber) of the plant material into simple sugars. The soluble sugars are good source of food and carbon;

Table 1. Amount of particular nutritional parameter upon storage under in vitro infection by Aspergilus flavus in red chili powder.

\begin{tabular}{cccccccccccc}
\hline $\begin{array}{c}\text { Storage } \\
\text { days }\end{array}$ & $\begin{array}{c}\text { Fungal Count } \\
(\mathrm{Log} \text { CFU } / \\
\mathrm{g}) * 10^{4}\end{array}$ & $\begin{array}{c}\text { Ash } \\
(\%)\end{array}$ & $\begin{array}{c}\text { Crude } \\
\text { fibre } \\
(\%)\end{array}$ & $\begin{array}{c}\text { Fat } \\
(\%)\end{array}$ & $\begin{array}{c}\text { Total } \\
\text { Protein } \\
(\%)\end{array}$ & $\begin{array}{c}\text { Total } \\
\text { sugars } \\
(\%)\end{array}$ & $\begin{array}{c}\text { RSA } \\
(\%)\end{array}$ & $\begin{array}{c}\text { Ascorbic } \\
\text { acid } \\
(\mathrm{mg} / 100 \mathrm{~g})\end{array}$ & $\begin{array}{c}\text { Total } \\
\text { Phenols } \\
(\mathrm{mg} / 100 \mathrm{~g})\end{array}$ & $\begin{array}{c}\text { Total } \\
\text { Carotenoids } \\
(\mathrm{mg} / 100 \mathrm{~g})\end{array}$ & $\begin{array}{c}\text { Total } \\
\text { capsiacin } \\
(\mu \mathrm{g} / 100 \mathrm{~g})\end{array}$ \\
\hline $\begin{array}{c}0 \\
\text { (control) }\end{array}$ & - & 9.75 & 18.98 & 13.325 & 18.01 & 32.89 & 96.78 & 86.98 & 495.26 & 133.65 & 995.395 \\
5 & 4.2 & 9.45 & 17.75 & 10.22 & 17.88 & 28.4 & 88.2 & 72.22 & 482.54 & 111.28 & 978.88 \\
10 & 6.8 & 8.42 & 15.46 & 8.88 & 14.2 & 24.18 & 63.43 & 64.48 & 480.22 & 112 & 548.8 \\
15 & 10.4 & 6.26 & 13.42 & 5.72 & 21.12 & 12.56 & 25.9 & 48.36 & 220.36 & 75.45 & 595.46 \\
20 & 18.82 & 3.42 & 8.6 & 2.23 & 22.45 & 4.74 & 18.82 & 28.96 & 218.89 & 23.35 & 620.15 \\
25 & 18.9 & 2.88 & 8.8 & 2.34 & 23 & 4.88 & 18.76 & 27.78 & 218.89 & 24.42 & 622.35 \\
30 & 17.5 & 2.88 & 7.78 & 2.42 & 23 & 4.75 & 18.72 & 26.28 & 218.26 & 15.29 & 621.38 \\
\hline
\end{tabular}




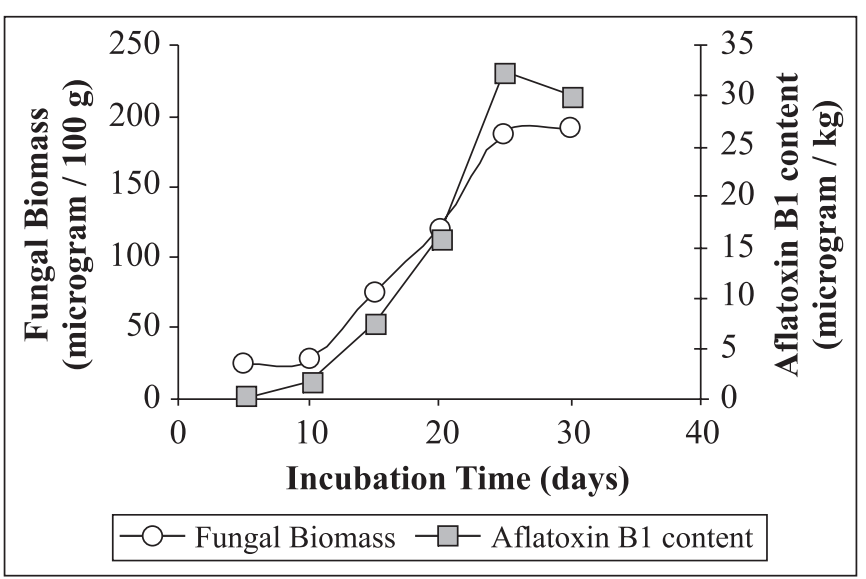

Figure 1. Effect of incubation time on fungal biomass and aflatoxin $\mathrm{B}_{1}$ production by $A$. flavus during in vitro infection in red pepper powder.

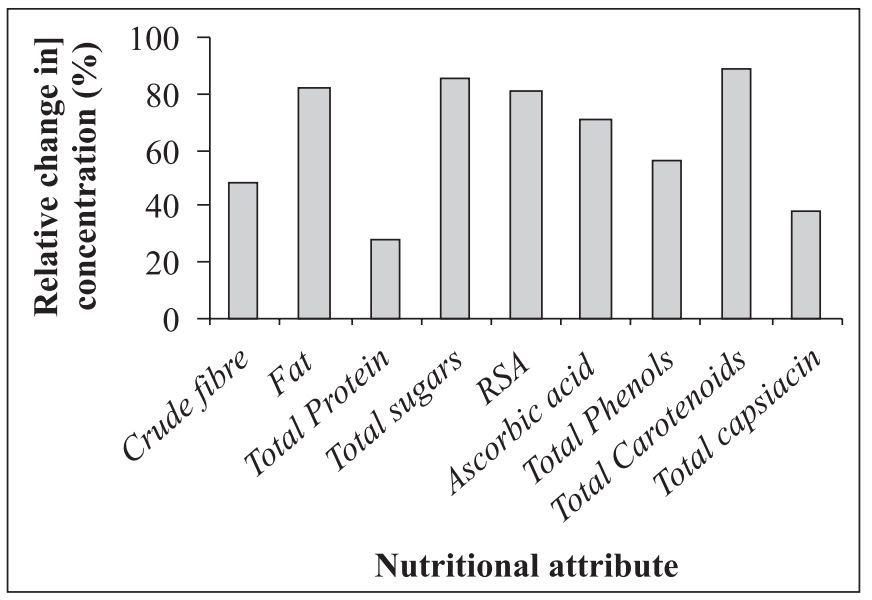

Figure 2. Percentage change in the biochemical constituent of powdered red pepper after 30 days of successful growth of Aspergillus flavus.

it is easily digested by the fungus. With the aid of extracellular enzyme system Aspergillus sp. successfully uptook the sugars present in chilli powder for its establishment is the reason for its depletion at the end of incubation. Rajarathnam et al. (20) also observed quantitative losses in Cellulose, hemicellulose(s), lignin, total carbon and total nitrogen during growth of Pleurotus flabellatus on rice straw.

There was drastic decrease in fat content from $13.32 \%$ to $2.42 \%$ ( $82.31 \%$ Loss); the breakdown of fat by lipases present in A. flavus for its uptake may be the reason for this. The decrease in ash content; which is an indicator of total mineral content of powder also was on similar trends as observed by
Aziz et al. (4); who reported that Aspergillus flavus depleted the zinc, copper and iron from the corn. Thus there is direct correlation between metal uptake and mould growth.

There was only $37 \%$ loss in capsaicin content, Fig. 2, the recorded loss in capsaicin content might be due to fungal enzymatic (peroxidases) oxidation of the vanninyl moiety into other secondary substances.

Carotenes are largely responsible for the color of the red peppers. Initially the color of the powdered red pepper was brilliant red but after 30 days of infection the powder was clearly looking moldy and dull colored. The carotenoids are very sensitive to oxidation and degradation in response to environmental stress. They are highly unstable and high relative humidity leads to enzymatic hydrolysis of the structure and in turn makes it susceptible to the oxidation and loss (10). It can also be hypothesized that during microbial growth there is increase in respiration rate which generates some amount of heat in the micro- atmosphere which may have effect on stability of carotenes. There are also reports on clevage of $\beta$-carotenes into some flavor compounds by fungi (28).

The loss in ascorbic acid content can be attributed to its vulnerability to light, oxidation and heat. The level reduced from 86.98 in control sample to $26.28 \mathrm{mg} / 100 \mathrm{~g}$ in highly infected sample at end of incubation (fungal biomass $192.25 \mathrm{mg} / 100 \mathrm{~g}$ powder). Aspergillus flavus secretes various phenolases in the substratum (15) and it is reported that vitamin $C$ is sensitive to phenol oxidases which facilitate its oxidation. The oxidation of polyphenols by phenolases may also be the reason for about $55.93 \%$ loss in polyphenolic content of the infected sample.

Free radical scavenging activity measured by DPPH assay depends upon the hydrogen donating ability of the antioxidants. Antioxidant activity is a function of various chemical compounds, of which phenols play an important role. Plant phenolics constitute one of the major classes of plant compounds which act as free radical scavengers. Other then phenolics, $\beta$-carotene and ascorbic acid are also good source of antioxidants. The investigated variety of red pepper had significantly good amounts of potent radical scavengers like $\beta$ carotene, ascorbic acid and total phenols and correspondingly strong RSA (96.78), Table 1. From the Fig. 2, it is observed that most of the biochemical constituents show more then $60 \%$ of nutritional losses after mould growth. All these factors lead to deterioration of the nutritional quality of chilli powder and significantly contribute to the low antioxidant potential (18.72) of the mould infected sample.

\section{CONCLUSIONS}

There are various reports on fungal colonization and aflatoxin production in red pepper, however there are no or limited studies on extent of $A$. flavus growth and consequently aflatoxin $\mathrm{B}_{1}$ production leading to quality changes in powdered red pepper 
during storage. Various biochemical changes caused by numerous other fungus in different food products are also reported. The present investigation reports for the first time the effect of A. flavus growth on nutritional content of chili powder. From the results it can be concluded; that the successful growth of A.flavus and aflatoxin production in red chili powder suggests it can be used as a good and cheap solid substrate for the fungal growth and aflatoxin $\mathrm{B}_{1}$ production. Inspite of the presence of pungent compounds in red chilies the high sugar and fat contents of chilies offer a good source of energy for the survival and establishment of the fungus. Appreciable amount of carotenoids in red chilies are also good source of carbohydrate for the mould growth. A. flavus produces various enzymes in the substrate during its growth which aid in its metabolism resulting in overestimation of the total protein content. Significant variations in important biochemical content between infected and control (mould free) samples indicates that mycoflora colonization produce some biochemical changes in the food properties during its growth. The fungus utilizes some of the constituents present in the red pepper for its growth leading to their quantitative differences and losses after fungal contamination. The changes that occur during infection and the resultant effect on nutritional quality are important dietary considerations. Some of these constituents are also important quality factors for export of the red pepper powder.

\section{ACKNOWLEDGMENT}

This research is supported by grant (No. SSD/SS/005/2005) from Government of India, Ministry of Science and Technology, Department of Science and Technology, New Delhi to Smita Tripathi, Indian Institute of Technology, Kharagpur-721302 under Women Scientists Scholarship Scheme for Societal Programmes (WOS-B).

\section{RESUMO}

\section{Alterações nutricionais em pimenta vermelha em pó após infecção in vitro com Aspergillus flavus}

Foram avaliadas as perdas de vários constituintes bioquímicos como capsaicina, carotenos, acido ascórbico, polifenóis, matéria orgânica, açucares (solúveis e insolúveis), proteína e gordura em pimenta vermelha em pó após a multiplicação de Aspergillus flavus por 30 dias. A biomassa fúngica foi mensurada pelo conteúdo de ergosterol e aflatoxina por HPLC. Entre os vários constituintes avaliados, a maior perda foi a de carotenóides totais $(88,55 \%)$, seguido de açucares totais $(85,5 \%)$. O conteúdo protéico da amostra infectada aumentou de $18,01 \%$ para $23 \%$. O perfil nutricional da pimenta em pó (Capsicum annum var. sannam L.) indica alto teor de açucares totais $(32,89 \%)$ e fibras $(21,05 \%)$, seguido de proteína $(18,01 \%)$ e gordura $(13,32 \%)$, tornando-a um substrato ideal para crescimento de fungos. Ao final dos 30 dias, a biomassa fúngica foi $192,25 \mathrm{mg} / 100 \mathrm{~g}$, a contagem total em placas foi $17,5 \times 10^{4} \mathrm{CFU} / g$ e o conteúdo de aflatoxina B1 foi $30,06 \mu \mathrm{g} / \mathrm{kg}$.

Palavras-chave: Aspergillus flavus, pimenta em pó, alterações nutricionais, aflatoxina

\section{REFERENCES}

1. Aquino, S.; Ferreira, F.; Ribeiro, D.H.B.; Corrêa, B.; Greiner, A.; Villavicencio, A.L.C.H. (2005). Evaluation of viability of Aspergillus flavus and aflatoxins degradation in irradiated samples of maize. Braz. J. Microbiol. 36 (4), 352-356.

2. Association of Official Analytical Chemists. (1990). Official methods of analysis, Washington, D.C. 14th edition, pp. 125- 878.

3. Azad, P. (1991). Fate and role of chemical constituents of chilli fruits during infection with Colletotrichum capsici, Indian Phytopathology. 44, 129-131.

4. Aziz, N.H.; Shahin, A.A.M.; Abou-Zeid, A.A.M.; El-Zeany, S.A (2000). Correlation of growth and aflatoxin production by Aspergillus flavus with some essential metals in gamma irradiated crushed corn. Food. 44 (5), 354-359.

5. Banerjee, M.; Sarkar, K.P. (2003). Microbiological quality of some retail spices in India. Food Res. Intern. 36, 469-474.

6. Bankole, S.A.; Adebanjo, A. (2003). Mycotoxins in food in West Africa: current situation and possibilities of controlling it. Afr. J. Biotechnol. 2 (9), 254-263.

7. Bhardwaj, S.S.; Sharma, S.L.; Thakur, P.D. (1985). Changes in phenolic and sugar content in bell pepper infected with Phytophthora nicotianae var. nicotianae. Indian Phytopathology. 38, 759.

8. Brand-Williams, W.; Cuvelier, M.E.; Berset, C. (1995). Use of free radical method to evaluate antioxidant activity, Lebensm. Wiss. Technol. 28, 25-30.

9. Christensen, C.M.; Fause, H.A.; Nelson, G.H.; Fern Band Mirocha, C.J. (1967). Microflora of black and red pepper. Appl. Microbiol. $15,622-626$.

10. Desobry, S.A.; Netto, F.M.; Labuza, T.P. (1998). Preservation of $\beta$ Carotene from Carrots. Crit. Rev. Food Sci. Nutr. 38 (5), 381-396.

11. Flannigan, B.; Hui, S.C. (1976). The occurrence of aflatoxin producing strains of Aspergillus flavus in the mold flora of spices. J. Appl. Bacteriol. 41, 411-418.

12. Folin, O.; Ciocalteu, V. (1972). On tyrosin and tryptophane determination in proteins. J. Biol. Chem. 27, 627-650.

13. Jelinek, C.F.; Pohland, A.E.; Wood, G. (1989). Worldwide occurrence of mycotoxins in food and feeds. J. Assoc. Off. Anal. Chem. 72, 223-230.

14. Jones, E.; Hughes, R.E. (1983). Foliar ascorbic acid in some angiosperms. Phytochemistry. 22, 2493-2499.

15. Medina, A.; Mateo, R.; Lopez-Ocana, L.; Valle-Algarra, F.M.; Jimenez, M. (2005). Study of Spanish grape mycobiota and ochratoxin A production by Isolates of Aspergillus tubingensis and other members of Aspergillus section Nigri. Appl. Environ. Microbiol. 71, 4696-4702.

16. Naewbanij, M.; Seib, P.A.; Burroughs, R.; Seitz, L.M.; Chung, D.S. (1984). Determination of Ergosterol Using Thin-Layer Chromatography and Ultraviolet Spectroscopy. Cereal Chem. 6, 1 (5), 385-388.

17. Onifade, A.K.; Agboola, Y.A.J. (2003). Effect of fungal infection on proximate nutrient composition of coconut (Cocos nucifera Linn) fruit. Food, Agric. Environ. 1 (2), 141-142. 
Tripathi, S. et al.

18. Patel, S.; Hazel, C.M.; Winterson, A.G.M.; Morthy, E. (1996). Survey of ethnic foods for mycotoxins. Food Addit. Contam. 7, 833-841.

19. Prasad, B.K.; Sahoo, D.R.; Mandojkumar; Naresh (2000). Mycotoxins in spices, Voprosy pitaniya. 69, 40-43.

20. Rajarathnam, S.; Wankhede, D.B.; Patwardhan, M.V. (1979). Some chemical and biochemical changes in straw constituents during growth of Pleurotus flabellatus (Berk \& Br) Sacc. European J. Appl. Microbiol. Biotechnol. 8, 125-134.

21. Reddy, S.V.; Kiranmayi, D.; Umareddy, M.; Thirumala Devi, K.; Reddy, D.V.R. (2001). Aflatoxin $\mathrm{B}_{1}$ in different grades of chillies (Capsicum annuиm) in Indian as detected by indirect competitive ELISA. Food Addit. Contam. 18, 553-558.

22. Sadasivam, S.; Manikkam, A. (1992a). Capsaicin. In Biochemical methods for agricultural sciences (pp. 193-194). New Delhi: Wiley Eastern Limited.
23. Sadasivam, S.; Manikkam, A. (1992b). Carotenes. In Biochemical methods for agricultural sciences (pp. 187-188). New Delhi: Wiley Eastern Limited.

24. Sauer, B.D. (1988). Effects of fungal deterioration on grain: nutritional value, toxicity, germination. Int. J. Food Microbiol., 7, 267-275.

25. Scott, P.M.; Kennedy, B.P.C. (1973). Survey of ground black, white and capsicum peppers for aflatoxins. J. Assoc. Agric. Chem. 56, $1452-1457$.

26. Seenappa, M.; Stobbs, L.W.; Kempton, A.G. (1980). Aspergillus colonization of Indian red pepper during storage. Phytopathology. 70, 218-222.

27. Vasanthi, S.; Bhat, R.V.; Subbulakshmi, G. (1999). Aflatoxin Intake from Maize-Based Diets in a Rural Population in Southern India. $J$. Sci. Food Agric. 73 (2), 226-230.

28. Zorn, H.; Langhoff, S.; Scheibner, M.; Berger, R.G. (2003). Cleavage of $B, B$-carotene to flavor compounds by fungi. Appl. Microbiol. Biotechnol. 62 (4), 331-336. 